\title{
Siberian Husky
}

National Cancer Institute

\section{Source}

National Cancer Institute. Siberian Husky. NCI Thesaurus. Code C53778.

The Siberian Husky is a strong, compact, working dog with high set and erect ears. The large "snow shoe" feet have hair between the toes for gripping on ice. It has a thick, wooly undercoat and soft outer coat. Color choices include Black and White, which ranges from light (dilute) to dark (jet); Red and White, which rang es from light (peach or orange) to dark (chocolate or brown); Gray and White, which ranges from light (silver) to dark (wolf-gray); Sable and White (which is red-orange with black tips); Agouti and White (which is sometimes referred to as the coyote color), and White. The face mask and underbody are usually white. Height: 20-23 1/2 inches $(51-60 \mathrm{~cm}$.) Weight: 35-60 pounds $(16-27 \mathrm{~kg}$.) 